\title{
Economic Policy Uncertainty and Enterprise Earnings Information Content: Evidence from China
}

\author{
Du Guoliang, Du Xunliang, Lin Wen* \\ School of Accounting, Wuhan Textile University, Wuhan, China \\ Email address: \\ 95255286@qq.com (Du Guoliang),whfdkjxy@163.com (Du Xunliang),79878957@qq.com (Lin Wen) \\ ${ }^{*}$ Corresponding author
}

\section{To cite this article:}

Du Guoliang, Du Xunliang, Lin Wen. Economic Policy Uncertainty and Enterprise Earnings Information Content: Evidence from China. International Journal of Economics, Finance and Management Sciences. Vol. 9, No. 5, 2021, pp. 203-209. doi: 10.11648/j.ijefm.20210905.15

Received: September 9, 2021; Accepted: October 19, 2021; Published: October 29, 2021

\begin{abstract}
Earnings information as a key factor affecting investors' decisions, has attracted much attention from scholars in recent years. Based on the data of A-share listed companies from 2002 to 2019, this paper examines the impact of economic policy uncertainty on earnings information content of enterprises through multiple linear regression, empirical results show that: 1. the benchmark results show that the uncertainty of economic policy significantly improves the earnings information content of enterprises. The above conclusions still hold after changing the uncertainty index of economic policy, carrying out the lag and lag treatment during the uncertainty of economic policy, and carrying out the robustness test by changing the measure method; 2 . mechanism studies show that enterprises are more likely to attract investors' attention under uncertain environment, and the "supervision" pressure from investors forces enterprises to reduce earnings management and increase information disclosure, thus enhancing investors' trust in corporate earnings; 3 . the expansion study found that the more high-quality accounting information, so as to establish a good corporate reputation among investors. The research conclusion not only expands the existing literature on the impact of economic policy uncertainty on the content of corporate earnings information, but also provides a new perspective and new empirical evidence for understanding whether and how the uncertainty of economic policy will affect the content of corporate earnings information, and has a certain practical significance.
\end{abstract}

Keywords: Economic Policy Uncertainty, Earnings Information Content, Quality of Accounting Information

\section{Introduction}

Information is the lifeblood of capital market [1], and earnings information is the cornerstone for investors to make decisions. Plenty of earnings information content not only means that market participants have a high degree of trust in earnings information of enterprises. It also implies that investors will be more willing to pay for enterprises with better profits, and the "content" of external trust generated by it will help improve the efficiency of market resource allocation, reduce the cost of capital of enterprises [2], and improve stock value [3].

In existing studies, scholars have carried out abundant theoretical analysis and empirical tests on the content of enterprise earnings information by focusing on internal factors such as internal control and political connection, but they do not pay much attention to whether the external environment will affect the output of enterprise information. In particular, as the world is facing unprecedented changes in a century, a large number of policy announcements and media information pour into the capital market, aggravating the cost and difficulty for investors to capture private value signals from the public market and making investors more willing to focus on the overall market factors, so relaxed focus on specific aspects of the enterprise information, it's for the enterprise surplus information of "fake and fraud" created "valuable" opportunity, with the passage of time, once this kind of "bad news" cannot be hidden, not only a heavy impact on the operation of the capital market order, and more will deteriorate investors trust private information to the enterprise level, cause trust collapse, Eventually lead to a substantial drop in the content of enterprise surplus information [4-6].

But for China's retail-dominated capital markets, investor caution seems to offer a plausible eastern diagnosis of the external disease of economic policy uncertainty. Specifically, in the face of increasingly uncertain policy environment, it is increasingly difficult for investors to obtain private value 
signals from the public market. However, due to the investment psychology of risk aversion, domestic investors are more likely to collect private information from all parties in the market to make up for the lack of public information, this not only enables investors to obtain more accurate corporate information, but also makes it more likely that the prudent behavior of investors will form external supervision forces to urge enterprises to release more authentic and reliable earnings information, thus improving the content of corporate earnings information.

The marginal contribution of this paper is reflected in the following aspects:

First, despite scholars from corporate investment, financing, innovation and commercial credit, surplus management perspective to explore the economic policy to the enterprise microscopic behavior of the impact of uncertainty, but this article from the economic policy of uncertain "reverse governance", the empirical conclusion instead of uncertain economic policy environment to enhance the investor's trust in the enterprise surplus information, This not only opens a new view in the field of macroeconomic policy, but also proves that market participants can reasonably perceive changes in the external environment and make positive feedback in the "negative" environment of policy uncertainty.

Second, existing literature discusses the factors influencing the content of corporate earnings information from multiple perspectives, such as internal control, characteristics of the board of directors, company size, growth opportunities and corporate social responsibility. However, there is almost no research on whether economic policy uncertainty will affect the content of corporate earnings information. From the unique perspective of economic policy uncertainty, this paper deeply analyzes the logical chain between economic policy uncertainty and corporate earnings information content, which provides a new clue for further exploring the macro environment and earnings information content.

Thirdly, the paper not only reveals the specific path of economic policy uncertainty affecting earnings information content from the perspective of investors' attention, at the same time, in order to explore an effective way to improve enterprise surplus information content, the article empirical to quality the better the enterprise internal control will be more vulnerable to investors' trust, indicates that the development of enterprises not only need the external environment constraints, enterprises should actively promote the internal management level, to give high quality of financial information to the market, realize sustainable development.

The following analysis is organized as follows. The second part is theoretical analysis and research hypothesis, the third part is research design, the fourth part is empirical analysis, and the fifth part is conclusion.

\section{Theoretical Analysis and Research Hypothesis}

First of all, from the perspective of investors, Hirshleifer and Teoh (2003) thought that investors' attention to information was an expensive activity according to the theory of "limited attention" [7]. As a result, only a small number of investors (those with information) observe corporate information, while for the vast majority of retail investors (those without information), As a natural "signal lamp" of enterprise's operating condition, stock price has its own information attribute which can help it to make decision. However, Drobetz (2008) and other scholars found that with the increasing uncertainty of economic policies, the ability of stock price to "absorb" corporate trait information was decreasing [8]. The amount of firm-specific information that retail investors "capture" from the equilibrium price of the stock is also greatly reduced, For the sake of risk aversion, these investors will be more specific information, is willing to dig the enterprise level and these investors concerned about the company information to a certain extent increased external supervision enterprise pressure, under external examination and owner punishment risk, management of precautionary motive, greatly reduce the chances of the earnings manipulation, Thus, it is helpful to improve the trustworthy level of earnings information and increase the content of earnings information.

Secondly, Nagar et al. (2019) found that economic policy uncertainty raised the level of information asymmetry among market participants and increased the uncertainty of business operation [6]. At this point, investors will demand higher investment returns and more stringent loan agreements to compensate for the additional risks caused by policy uncertainty, banks and other financial institutions will also reduce loan supply to avoid the risk of bad debts [9-10]. So, in the face of high external financing constraints, the enterprise management in order to seek the market investors, Banks and other financial institutions to finance trust, get plenty of money supply, more inclined to by adding information disclosure [11], voluntary earnings forecast [12], and other ways to ease the information asymmetry of enterprise and market participants, This not only helps banks and other financial institutions to better evaluate the company's development prospects and reduce the external financing pressure of enterprises, but also provides more internal information for the majority of investors to help them correctly interpret the financial reports of enterprises, thus increasing investors' trust in enterprises and improving the content of earnings information.

Although enterprises face higher financing constraints in the context of uncertain economic policies, Cao et al. (2019) believe that enterprise managers are more likely to transmit their good future earnings expectations to the market and reduce financing costs through upward earnings management during uncertain economic policies [13]. At the same time, Detzel et al. (2015) also found that uncertainty of economic policies aggravated the possibility of stock price decline of enterprises [14]. In order to avoid the negative impact of stock price decline, corporate executives are more likely to "rescue" stock price through earnings management activities under the "cover" of information asymmetry. However, earnings management as the enterprise adjust or distortion of accounting information "hidden" means, by changing the accrued items metering and control in order to achieve real business activities affect the purpose of financial 
reporting information, lead to enterprise financial information transparency is greatly reduced, the trust level of the investors for enterprise surplus, the surplus information content is lower.

Based on the above analysis, this paper proposes the following hypothesespp.

H1a: Control other variables, economic policy uncertainty and corporate earnings information content has a significant positive relationship.

H1b: Control other variables, economic policy uncertainty and corporate earnings information content has a significant negative relationship.

\section{Research Design}

\subsection{Sample Selection and Data Sources}

In this paper, all A-share listed companies in Shanghai and Shenzhen stock markets from 2008 to 2019 were selected as the research samples, and 9293 observed values were obtained after excluding financial enterprises, ST, * ST enterprises and samples with missing financial data. All financial data and stock trading data in this paper are from CSMAR database. In order to protect the results from some extreme OBSERVATIONS, the continuous variables were curtailed in the upper and lower $1 \%$ quartiles. Stata16.0 is used for data processing.

\subsection{Model Design and VARIABLE Description}

\subsubsection{Model Design}

Based on the research results of Fan and Wong (2002) [15], this paper puts the economic policy uncertainty index into the traditional earnings -- market response model, and uses the earnings index and the economic policy uncertainty index multiplier (NI*EPU) to test hypothesis H1. Therefore, this paper constructs model (1).

$$
C A R=\alpha_{0}+\alpha_{1} N I+\alpha_{2} E P U+\alpha_{3} N I * E P U+\alpha_{i} \sum C O N T R O L S+\varepsilon
$$

\subsubsection{VARIABLE Description}

(1) Explained variables. Adopting the research methods of Fan and Wong (2002) and Jiang et al. (2016) [15, 16], this paper takes the cumulative excess return (CAR) as a proxy variable to measure the content of earnings information of enterprises, calculates the excess return on a monthly basis and sums it up on a yearly basis to calculate the annual cumulative excess return. The specific process is as follows.

First, monthly excess returns are calculated based on market adjustment models

$$
\mathrm{AR}_{\mathrm{i}, \mathrm{t}}=\mathrm{R}_{\mathrm{i}, \mathrm{t}}-\mathrm{ER}_{\mathrm{i}, \mathrm{t}}
$$

$A_{i, t}$ represents the monthly excess return rate, $R_{i, t}$ represents the real rate of return in month $\mathrm{i}, \mathrm{ER}_{\mathrm{i}, \mathrm{t}}$ is the normal rate of return of the $t$ sample unit in month I estimated according to the market adjustment method, When the two are subtracted, the excess return rate of company $\mathrm{T}$ in month $\mathrm{i}$ is obtained.

Secondly, according to the practice of Yu et al. (2013) [17], replace the normal return rate of individual stocks with the return rate of Shenzhen Stock Exchange.

$$
\mathrm{ER}_{\mathrm{i}, \mathrm{t}}=\mathrm{RM}_{\mathrm{i}, \mathrm{t}}
$$

Finally, calculate the cumulative excess return of individual stocks in the event period.

$$
C A R=C A R_{i}=\sum_{t=t 1}^{t 2} A R_{i, \mathrm{t}}
$$

CAR is the cumulative excess return rate of Company $i$ in 12 months of year T.

(2) Core explanatory variables. Based on the ideas of Wang et al. (2014) and Rao et al. (2016), this paper adopts Baker et al. (2016) to calculate the uncertainty index of China's economic policy to measure the uncertainty degree of China's economic policy [18-20]. According to the research method of Wang and $\mathrm{Hu}$ (2020) [21], The cross term (NI*EPU) of corporate surplus level and economic policy uncertainty index (EPU) is taken as the core explanatory variable of this study.

Table 1. VARIABLE definition table.

\begin{tabular}{lll}
\hline VARIABLE types & VARIABLE symbol & Define \\
\hline Explained VARIABLE & CAR & Annual cumulative excess return \\
Explanatory variables & EPU & Baker et al. (2016) Measuring the uncertainty index of economic policy \\
& NI & Ending net profit/ending owner's equity \\
& ROA & Annual net profit/Year-end total assets \\
& SIZE & The natural log of total assets at year end \\
& LEV & Year-end total liabilities/year-end total assets \\
& SHARE & Shareholding ratio of the largest shareholder \\
& BS & Number of board members \\
INDEP & Number of independent directors/number of directors \\
& GROWTH & (Stock market value + net debt)/Total assets \\
& MAN & If the enterprise management holds shares, the value is $1 ;$ otherwise, the value is 0 \\
& SOE & The actual controller is a state-owned enterprise. The value is 1. Otherwise, the value is 0 \\
& AUDIT & The value of the company audited by the Big Four accounting firms is 1 , otherwise it is 0 \\
& DUAL & If yes, the value is 1; otherwise, the value is 0 \\
& lnd & Industry dummy VARIABLE \\
& Year & Year dummy VARIABLE \\
\hline
\end{tabular}


(3) Control variables. Based on the research results of Zhu (2011) and Yu et al. (2013) [22, 17], For enterprise size (SIZE), return on equity (ROE), growth opportunity (GROWTH), asset-liability ratio (LEV), director and the manager shall be one (DUAL), board independence
(INDEP), shareholding ratio of the largest shareholder (SHARE), management shareholding (MAN), board size (BS), At the same time, annual and industry effects are also controlled. The specific variables defined or measured in the model are shown in Table 1.

Table 2. Descriptive statistics.

\begin{tabular}{|c|c|c|c|c|c|}
\hline VARIABLE & Sample Size & Mean & standard & Min & Max \\
\hline CAR & 9293 & -0.0017 & 0.3595 & -0.7701 & 1.2456 \\
\hline NI & 9293 & 0.0632 & 0.122 & -0.5982 & 0.3985 \\
\hline EPU & 9293 & 5.3928 & 0.5296 & 4.5940 & 6.1322 \\
\hline ROA & 9293 & 0.0273 & 0.0725 & -0.3419 & 0.1971 \\
\hline GROWTH & 9293 & 2.4986 & 1.9196 & 0.8731 & 12.6999 \\
\hline SHARE & 9293 & 33.558 & 14.9351 & 8.5 & 74.295 \\
\hline BS & 9293 & 8.5659 & 1.7547 & 5 & 15 \\
\hline INDEP & 9293 & 0.3756 & 0.0536 & 0.3333 & 0.5714 \\
\hline LEV & 9293 & 0.4579 & 0.211 & 0.059 & 0.9415 \\
\hline SIZE & 9293 & 22.1047 & 1.3218 & 19.5025 & 26.1079 \\
\hline AUDIT & 9293 & 0.0468 & 0.2113 & 0 & 1 \\
\hline SOE & 9293 & 0.3765 & 0.4845 & 0 & 1 \\
\hline DUAL & 9293 & 0.2583 & 0.4377 & 0 & 1 \\
\hline MAN & 9293 & 0.6583 & 0.4743 & 0 & 1 \\
\hline
\end{tabular}

\section{The Empirical Analysis}

\subsection{Descriptive Statistics}

Table 2 shows the descriptive statistical results of variables. The mean value of cumulative excess return (CAR) is -0.0017 , and there is a large difference between the minimum value $(-0.7701)$ and the maximum value (1.2456), indicating that the overall earnings of enterprises are not optimistic under the circumstance of low macroeconomic situation. The mean value of earnings index (ni) is 0.0632 , which is very close to the median (0.0672), indicating that the sample earnings distribution is relatively uniform. The mean value of economic policy uncertainty (EPU) was 5.3928, indicating that Chinese enterprises faced a high level of economic policy uncertainty during the sample period. The descriptive statistical results of other variables are shown in Table 2.

Table 3. Regression results of economic policy uncertainty and earnings information content benchmark.

\begin{tabular}{|c|c|c|c|c|c|}
\hline \multirow{2}{*}{ VARIABLE } & CAR & CAR & CAR & CAR & CAR \\
\hline & (1) & $(2)$ & (3) & (4) & (5) \\
\hline NI & $0.5226 * * *(16.6356)$ & $0.4155 * * *(11.7922)$ & $-0.7289 * *(-2.4021)$ & $-0.2028(-0.7347)$ & $-1.4810 * * *(-4.5549)$ \\
\hline EPU & & & $0.0394 * * *(3.6243)$ & & \\
\hline$I^{*} \mathrm{EPU}$ & & & $0.2082 * * *(3.9082)$ & & \\
\hline AEPU & & & & $0.0551 * * *(4.6117)$ & \\
\hline NI*AEPU & & & & $0.1070 * *(2.3096)$ & \\
\hline LEPU & & & & & $-0.0055(-0.3450)$ \\
\hline NI*LEPU & & & & & $0.3554 * * *(6.0000)$ \\
\hline ROA & & $0.6186 * * *(11.6110)$ & $0.6232 * * *(11.7734)$ & $0.6238 * * *(11.7502)$ & $0.6226^{* * *}(11.7721)$ \\
\hline GROWTH & & $0.0476 * * *(14.3855)$ & $0.0474 * * *(14.4701)$ & $0.0476 * * *(14.4224)$ & $0.0476 * * *(14.5687)$ \\
\hline SHARE & & $-0.0004 *(-1.9533)$ & $-0.0004 * *(-2.0118)$ & $-0.0004 * *(-1.9702)$ & $-0.0004 * *(-2.1239)$ \\
\hline BS & & $-0.0018(-0.8994)$ & $-0.0019(-0.9494)$ & $-0.0018(-0.9389)$ & $-0.0019(-0.9594)$ \\
\hline INDEP & & $-0.1284 * *(-1.9793)$ & $-0.1279 * *(-1.9873)$ & $-0.1285 * *(-1.9908)$ & $-0.1249 *(-1.9327)$ \\
\hline LEV & & $0.1545^{* * *}(7.1880)$ & $0.1544 * * *(7.2288)$ & $0.1545 * * *(7.2050)$ & $0.1563 * * *(7.2844)$ \\
\hline SIZE & & $-0.0029(-0.8072)$ & $-0.0028(-0.7819)$ & $-0.0028(-0.7741)$ & $-0.0028(-0.7932)$ \\
\hline AUDIT & & $0.0020(0.1427)$ & $0.0027(0.1884)$ & $0.0021(0.1485)$ & $0.0029(0.2077)$ \\
\hline SOE & & $-0.0286 * * *(-4.2766)$ & $-0.0294 * * *(-4.4425)$ & $-0.0290 * * *(-4.3640)$ & $-0.0300 * * *(-4.5500)$ \\
\hline DUAL & & $-0.0017(-0.2259)$ & $-0.0024(-0.3168)$ & $-0.0022(-0.2939)$ & $-0.0021(-0.2755)$ \\
\hline MAN & & $0.0162 * *(2.4491)$ & $0.0172 * * *(2.6153)$ & $0.0169 * *(2.5565)$ & $0.0172 * * *(2.6121)$ \\
\hline CONSTANT & $-0.1050 * * *(-5.0241)$ & $-0.1392 *(-1.7960)$ & $-0.3030 * * *(-3.3723)$ & $-0.4173 * * *(-4.3067)$ & $-0.0982(-0.9191)$ \\
\hline OBSERVATIONS & 9,328 & 9,293 & 9,293 & 9,293 & 9,293 \\
\hline R-squared & 0.046 & 0.112 & 0.113 & 0.112 & 0.115 \\
\hline
\end{tabular}

Robust t-statistics in parentheses.

$* * * \mathrm{p}<0.01, * * \mathrm{p}<0.05, * \mathrm{p}<0.1$. 


\subsection{Analysis of Regression Results}

As can be seen from Columns (1) and (2) of Table 3, when no other control variables are added, corporate earnings level (NI) has a strong positive relationship with cumulative excess return (CAR), and the NI regression coefficient is 0.5226, which passes the significance test at $1 \%$ level. After the addition of control variables, the NI regression coefficient is 0.4155 and is significant at $1 \%$ level. The above conclusions confirm the existence of earnings information content of listed companies in China. Therefore, this paper continues to investigate the influence relationship between economic policy uncertainty and earnings information content. Column (3) shows the regression results after adding the NI*EPU cross term of earnings income and economic policy uncertainty. The coefficient of the core explanatory VARIABLE (NI*EPU) is 0.2082 and passes the significance test at $1 \%$ level, which means that the higher the uncertainty level of economic policy is, the earnings can be reflected in the stock price more quickly, and the earnings information content increases significantly, because hypothesis H1 is confirmed. In columns (4) and (5), the economic policy uncertainty index is put into model (1) for regression again after matching $\mathrm{T}+1$ year and $\mathrm{T}-1$ year. It is found that both NI*AEPU and NI*LEPU coefficients are significantly positive, indicating that the impact of economic policy uncertainty on enterprise earnings information content has a certain persistence.

\subsection{Mechanism Testing}

Although the above research conclusions confirm that under the background of uncertain economic policies, the content of corporate earnings information will be significantly increased, how does the change of macro environment trigger the micro individual behavior? In particular, how does economic policy uncertainty increase investor confidence in corporate earnings?

Starting from investors to focus on the logical chain, on the basis of the above theoretical deduction, this paper expounds the policy environment of uncertain fuel investors through price "grab" the difficulty of enterprise quality information, in order to avoid the decision error, investors can increase the degree of attention to enterprise information, in the face of rising pressure of external supervision, enterprise will pay more attention to the annual report and information disclosure quality, Thus, the trust level of investors on earnings information will be improved from the supply side.

Therefore, based on the ideas of Quan and $\mathrm{Wu}$ (2010) [23], this paper uses the average turnover rate of 30 days before earnings announcement to measure investors' attention level, and makes group regression of investors' attention level according to the average value of the industry.

As can be seen from the regression results in Table 4, the NI*EPU coefficient is 0.2108 in the group with high investor concern and passes the significance test at $1 \%$ level, while in the group with low investor concern, the NI*EPU coefficient is 0.0942 but not significant, indicating that in an uncertain environment, Higher investor concern with external supervision function, effective constraint management earnings management motivation, improving the quality of corporate earnings, to enhance the level of investor confidence in the enterprise surplus, on the contrary, those from investors "favor" likely to engage in earnings management behavior of enterprise, the enterprise accounting information quality, therefore investors for surplus decreases in the level of trust This just reveals the inherent logic that investors focus on the uncertainty of economic policy and the content of earnings information, confirming the theoretical deduction above.

Table 4. Tests the mechanism based on investors' concerns.

\begin{tabular}{llll}
\hline \multirow{2}{*}{ VARIABLE } & ALL & High investor concern & Low investor concern \\
\cline { 2 - 4 } & CAR & CAR & CAR \\
\cline { 2 - 4 } & $\mathbf{( 1 )}$ & $\mathbf{( 2 )}$ & $\mathbf{( 3 )}$ \\
\hline NI & $-0.7289^{* *}(-2.4021)$ & $-0.6744(-1.4207)$ & $-0.1833(-0.4582)$ \\
EPU & $0.0394 * * *(3.6243)$ & $0.0269(1.0346)$ & $0.0834 * * *(6.1920)$ \\
NI*EPU & $0.2082^{* * *}(3.9082)$ & $0.2108^{* * *}(2.5920)$ & $0.0942(1.2981)$ \\
CONTROLS & YES & YES & YES \\
CONSTANT & $-0.3030^{* * *}(-3.3723)$ & $-0.1017(-0.4648)$ & $-0.8970^{* * *}(-8.2763)$ \\
OBSERVATIONS & 9,293 & 3,429 & 5,864 \\
R-squared & 0.113 & 0.141 & 0.142 \\
\hline
\end{tabular}

Robust t-statistics in parentheses.

${ }^{* * *} \mathrm{p}<0.01,{ }^{* *} \mathrm{p}<0.05,{ }^{*} \mathrm{p}<0.1$.

\subsection{Robustness Test}

(1) Test based on PSM (Propensity score matching method). Since the cumulative excess return (CAR) of enterprises is affected by many factors, sample self-selection bias is inevitable. In this paper, PSM method is used to screen and match samples to buffer the interference caused by sample self-selection.

Through PSM, table 5 shows the basic regression results, the first (1) column, don't add economic policy uncertainty index, proves the existence of surplus information content, the first column (2), the core variable coefficient of NI*EPU in 0.2506 and a significant at $1 \%$ level, which consistent with the conclusion above, the main test. 
Table 5. Robustness test based on PSM.

\begin{tabular}{lll}
\hline \multirow{2}{*}{ VARIABLE } & CAR & CAR \\
\cline { 2 - 3 } & $\mathbf{( 1 )}$ & $\mathbf{( 2 )}$ \\
\hline $\mathrm{N}$ & $0.4101 * * *(10.7914)$ & $-0.9627 * * *(-2.9772)$ \\
EPU & $0.0491^{* * *}(4.4549)$ & $0.0301 * *(2.5659)$ \\
NI*EPU & & $0.2506 * * *(4.4028)$ \\
CONTROLS & YES & YES \\
CONSTANT & $-0.3275^{* * *}(-3.4632)$ & $-0.2195 * *(-2.2780)$ \\
OBSERVATIONS & 8,380 & 8,380 \\
R-squared & 0.093 & 0.096 \\
\hline
\end{tabular}

Robust t-statistics in parentheses.

$* * * \mathrm{p}<0.01, * * \mathrm{p}<0.05, * \mathrm{p}<0.1$.

Table 6. Alternative economic policy uncertainty index.

\begin{tabular}{lll}
\hline \multirow{2}{*}{ VARIABLE } & CAR & CAR \\
\cline { 2 - 3 } & $\mathbf{( 1 )}$ & $\mathbf{( 2 )}$ \\
\hline NI & $0.4155^{* * *}(11.7922)$ & $-0.4723 * * *(-2.7703)$ \\
TPU & $0.0521 * * *(5.2906)$ & $0.0435 * * *(4.3764)$ \\
NI*TPU & & $0.1792 * * *(5.6345)$ \\
CONTROLS & YES & YES \\
CONSTANT & $-0.3811 * * *(-4.3269)$ & $-0.3348 * * *(-3.8220)$ \\
OBSERVATIONS & 9,293 & 9,293 \\
R-squared & 0.112 & 0.115 \\
\hline
\end{tabular}

Verification based on alternative economic policy uncertainty indicators. To ensure more reliable research conclusions and avoid regression bias caused by different measurement methods, Trade Policy Uncertainty, which is constructed by Huang and Luk (2019) [24], is introduced, referring to the research ideas of Deng and Ren (2020) [25]. In table 6 the NI coefficient in column (1) is significantly positive, and the surplus information content exists. In Column (2), the core explanatory VARIABLE NI*TPU coefficient is 0.1792 , which passes the significance test at $1 \%$ level, and the regression result is robust.

\subsection{Further Analysis}

Good internal control structure and level of management can not only improve enterprise accrued from the steady quality, constraints, surplus management, security, in order to maintain the reliability of accounting information, and uncertain economic policy background, have high quality of internal control of enterprises can be a complete representation of the internal control defects existing in the enterprise and the detailed disclosure of remedial measures, and thus improve enterprise's credit level. Therefore, enterprises with better internal control quality not only deliver high-quality accounting information to the market, but also convey to investors the positive management attitude of enterprise management and the determination to correct mistakes and win the trust and favor of market investors more easily with strict internal control design and sufficient information disclosure.

To this end, this paper draws on the research of Huang et al. (2017) [26] and uses The Dibo·Internal Control Index of Chinese Listed Companies to perform group regression on model (1) according to the industry average (see Table 7 for the results). Study found that the internal control in a group of high quality, surplus information content increased significantly, and low quality of internal control in a group, NI * EPU coefficient is positive but not significant, the revelation of the listed company, policy in uncertain environment, want to win the trust of the market investors and attention, you must strive to improve their internal control level, only to achieve the "who", Investors are more likely to be lenient and pour money into the corporate reservoir.

Table 7. Group inspection based on internal control quality.

\begin{tabular}{llll}
\hline \multirow{2}{*}{ VARIABLE } & ALL & High quality of internal control & Low internal control quality \\
\cline { 2 - 4 } & $\boldsymbol{C A R}$ & $\boldsymbol{C A R}$ & $\mathbf{C A R}$ \\
\cline { 2 - 4 } & $\mathbf{( 1 )}$ & $\mathbf{( 2 )}$ & $\mathbf{( 3 )}$ \\
\hline$N I$ & $-0.7289 * *(-2.4021)$ & $-1.7376^{* * *(-3.3392)}$ & $-0.2593(-0.6298)$ \\
NPU & $0.0394 * *(3.6243)$ & $0.0342 * *(2.1981)$ & $0.0143(0.6798)$ \\
CONEPU & $0.2082 * * *(3.9082)$ & $0.3923 * * *(4.2713)$ & $0.1132(1.5642)$ \\
CONSTANT & YES & YES & YES \\
OBSERVATIONS & $-0.3030 * * *(-3.3723)$ & $-0.1813(-1.4850)$ & $-0.2693(-1.6090)$ \\
$R$-squared & 9,293 & 5,814 & 3,479 \\
\hline
\end{tabular}

Robust t-statistics in parentheses

$* * * \mathrm{p}<0.01, * * \mathrm{p}<0.05, * \mathrm{p}<0.1$.

\section{Conclusions}

The research conclusion of this paper not only extends the existing literature on the impact of economic policy uncertainty on the content of corporate earnings information, but also provides a new perspective and new empirical evidence for understanding whether and how the uncertainty of economic policy will affect the content of corporate earnings information, and has certain practical enlightenment. First of all, from the government level, policymakers face uncertain economic policy to the environmental governance effect of capital market operation, but this does not mean to rely on policy uncertainty to stabilize the market order, the government department should follow the market rules and capital ecosystem of natural law, give full play to the market in resource allocation and the decisive role of economic activity directly, Make the market return to healthy operation by improving the competition mechanism of enterprises; Secondly, from the perspective of corporate governance, enterprises should strive to improve the level of internal control, and actively assume social responsibility. On the one 
hand, good internal control is conducive to the enterprise to deliver high-quality accounting information to the market. On the other hand, only the enterprise internal governance level and external regulatory environment work together to improve. In order to promote the progress and development of China's socialist market economic system to create greater opportunities.

Although this study reveals the positive relationship between economic policy uncertainty and corporate earnings information content from the perspective of investors' attention, it ignores the "information transmission" role played by analysts with information interpretation ability in the environment of macroeconomic policy uncertainty. Specifically, with their keen insight and policy sensitivity, analysts have more professional advantages in information collection, processing and interpretation, and can quickly convey the potential impact of external policy changes on enterprises to market investors, so as to alleviate the level of information asymmetry in the capital market. Therefore, will the accuracy of analysts' forecasts and the degree of concern have a good governance effect on the policy environment of information asymmetry? This will be the focus of our future research.

\section{References}

[1] S. Boubaker, and H. Sami. Multiple Large Shareholders and Earnings Informativeness [J]. Review of Accounting and Finance, 2011, vol. 3, pp. 246-266.

[2] D. Diamond, and V. Robert. Disclosure, Liquidity, and the Cost of Capital [J]. Journal of Finance, 1991, vol. 4, pp. 13251359.

[3] D. S. Gelb, and P. Zarowin. Corporate Disclosure Policy and the Informativeness of Stock Prices [J]. Review of Accounting Studies, 2002, vol. 1, pp. 33-52.

[4] L. Peng, and W. Xiong."Investor Attention, Overconfidence and Category Learning" [J], Journal of Financial Economics, 2006, vol. 3, pp. 563-602.

[5] M. Kacperczyk., S. Van Nieuwerburgh, and L. Veldkamp. "A Rational Theory of Mutual Funds' Attention Allocation" [J], Econometrica, 2016, vol. 2, pp. 571-626.

[6] V. Nagar, J. Schoenfeld, and L. Wellman. The Effect of Economic Policy Uncertainty on Investor Information Asymmetry and Management Disclosures [J]. Journal of Accounting and Economics, 2019, vol. 1, pp. 36-57.

[7] D. Hirshleifer, and S. H. Teoh. Limited Attention, Information Disclosure, and Financial Reporting [J]. Journal of Accounting and Economics, 2003, vol. 36, pp. 337-386.

[8] W. Drobetz, S. E. Ghoul, O. Guedhami, and M. J anzen. Policy Uncertainty, Investment, and the Cost of Capital [J]. Journal of Financial Stability, 2008, vol. 39, pp. 28-45.

[9] F. L. Zhang, y. Xu, y. q. Han, N. y. Sun, Economic Policy Uncertainty and Firm Financing Constraints [J]. Investment research, 2018, vol. 6, pp. 144-159.

[10] B. B. Francis, I. Hasan, and Y. Zhu. Political Uncertainty and
Bank Loan Contracting [J]. Journal of Empirical Finance, 2014, vol. 29, pp. 281-286.

[11] Q. L. Zhong, Y. Y. Liu, Are Analyst Reports More Informative In Times of Economic Policy Uncertainty? -- Based on the Dual Perspective of Investor Demand and Analyst Supply [J]. Accounting research, 2020, vol. 3, pp. 36-47.

[12] K. T. Zhou, S. S. Jiang, Z. M. MA, Political Uncertainty and Management's voluntary Performance Forecasting [J]. Accounting Research, 2017, vol. 10, pp. 65-70+97.

[13] Y. Cao, H. Dong, W. H. Cao, Economic Policy Uncertainty and Corporate Tax Evasion [J]. Securities Market Review, 2019, vol. 4, pp. 22-32.

[14] J. Brogaard, and A. L. Detzel. The Asset Pricing Implications of Government Economic Policy Uncertainty [J]. Social Science Electronic Publishing, 2015.

[15] J. Fan, and T. J. Wong. Corporate Ownership Structure and the Informativeness of Accounting Earnings in East Asia [J]. Journal of Accounting \& Economics, 2002, vol. 3, pp. 401425 .

[16] F. X. Jiang, B. B. Shi, Y. B. Ma, Financial Experience and Earnings Information Content of Directors secretaries [J]. Management World, 2016, vol. 9, pp. 161-173.

[17] F. Z, Yu, L. Ding, X. Xie, et al, Internal Control Information Disclosure, Market Evaluation and Earnings Information Content [J]. Audit Research, 2013, vol. 5, pp. 87-95.

[18] H. J. Wang, Q. Y. LI, F. Xin, Economic Policy Uncertainty, Cash Holding level and market value [J]. Financial Research Journal, 2014, vol. 9, pp. 53-68.

[19] P. G. Rao, M. Q. Shi, G. H. Jiang et al. Research on the Interaction between Macro-economic Policy and micro-firm Behavior. A Review of the first "Macro-economic Policy and micro-firm Behavior" Academic Conference [J]. Economic Research Journal, 2013, vol. 2, pp. 150-154.

[20] R. Baker, Scott, and Bloom. Measuring Economic Policy Uncertainty $[\mathrm{J}]$. The Quarterly Journal of Economics, 2016, vol. 4, pp. 1593-1636.

[21] X. Q. Wang, G. Q. Hu, Green Innovation, Corporate Reputation and Earnings Information Content [J]. Journal of Beijing Technology and Business University. Social Sciences, 2020, vol. 1, pp. 50-63.

[22] Q. Zhu, Corporate Social Responsibility, Market Evaluation and Earnings Information Content [J]. Accounting Research, 2011, vol. 11, pp. 27-34+92.

[23] X. F. Quan, S. N. Wu, Investor Attention, Earnings Announcement Effect and Management Announcement Choice [J]. Financial Research, 2010, vol. 11, pp. 90-107.

[24] Y. P. Huang. Luk, and B. M. Fleisher. Measuring Economic Policy Uncertainty in China [J]. China Economic Review, 2019, vol. 59, pp. 1-43.

[25] F. Deng, R. Ying, Trade Policy Uncertainty and Firm Innovation [J]. Journal of technology economics and management, 2020, vol. 12, pp. 30-35.

[26] Y. Huang, T. Y. Zhong, and Y. F. Liu, Internal Control Quality, Information Transparency and Share Price Information Content [J]. Journal of Zhongnan University of Economics and Law, 2017, vol. 3, pp. 14-23+158-159. 